RASĀYAN J. Chem.

Vol. 13 | No. 4 |2653-2663| October - December | 2020 ISSN: 0974-1496 | e-ISSN: 0976-0083 | CODEN: RJCABP

\title{
REMOVAL OF ALUMINUM (III) FROM POLLUTED WATER USING NEW EFFECTIVE BIO-SORBENTS DERIVED FROM STEMS OF Burea monosperma AND Angle marmelo PLANTS
}

\author{
Polavarapu Srineetha, Yeruva Alekhya Reddy, Sayana Veerababu \\ and K. Ravindhranath*
}

Department of Chemistry, K. L. University, Green Fields, Vaddeswaram-522 502, Guntur Dt., A.P., India

*E-mail: ravindhranath.kunta@gmail.com

\begin{abstract}
Highly effective sorbents are prepared from Burea monosperma stem powder (BMSP) and Angle marmelos stem powder (AMSP) for the removal of $\mathrm{Al}^{3+}$ from water. Extraction conditions are optimized. Adsorption capacities are as high as: $50.0 \mathrm{mg} / \mathrm{g}$ for BMSP and $62.0 \mathrm{mg} / \mathrm{g}$ for AMSP. Good extractions are observed in a wide range of $\mathrm{pH}$ : 3 to 9 with a maximum at $\mathrm{pH}: 8$, emphasizing the successful utility of both the adsorbents even in low acidic conditions. Common co-ions interfere marginally. Thermodynamic parameters reveal the spontaneity of sorption of $\mathrm{Al}^{3+}$ 'onto' the sorbents. Analysis of adsorption isotherms confirms Langmuir model of adsorption. Of the various kinetic models applied pseudo-second-order explains well the kinetics of $\mathrm{Al}^{3+}$ sorption. Both the spent sorbents can be regenerated and reused for three cycles with little loss of sorption capacities. BMSP and AMSP are successfully applied to remove completely $\mathrm{Al}^{3+}$ from the samples of industrial effluents as well as polluted lakes.

Keywords: Al-pollution Control, Bio-sorbents, Burea monosperma, Angle marmelo, Thermodynamics, Kinetics, Isotherms, Applications
\end{abstract}

(C) RASĀYAN. All rights reserved

\section{INTRODUCTION}

Aluminum is next to iron in human utility and it is abundantly available in the curst of earth ${ }^{1,2}$. In acidic environments, $\mathrm{Al}^{3+}$-ions leach into water bodies. ${ }^{1}$ Numerous industries based on Aluminum are the potential sources of contamination ${ }^{2}$. Ill-treated or un-treated sewages from these industries enter into water bodies. ${ }^{1-}$ ${ }^{3} \mathrm{As} \mathrm{Al}^{3+}$-salts are non-degradable, the Al-concentration increases in these water sources crossing the EPA maximum allowed limit of $0.2 \mathrm{ppm}^{3}$. Al intake is hazardous to human ${ }^{3-6}$ as well as to aquatic life ${ }^{7-10}$. Anemia, orthopedic ailments, neurological problems, brain hemorrhage etc., are some of the many problems caused by Al-intake. ${ }^{3-6}$

Hence removal $\mathrm{Al}^{3+}$ from contaminated water is one of the main aspects of water pollution control research. Earlier methods used are precipitating the $\mathrm{Al}^{3+}$ as $\mathrm{Al}(\mathrm{OH})_{3}$ by increasing solution pHs. These Precipitation methods are not satisfactory when $\mathrm{Al}^{3+}$-concentration is low. Reverse osmosis, electro dialysis and ionexchange methods of purification, though good, are non-economical and they are not adaptable to treat large amounts of water/sewage. ${ }^{11-17}$

Methods based on adsorption are attracting researchers as these procedures are simple and effective. ${ }^{18-20}$ When adsorbents are derived from plant materials, the adsorption process is becoming more interesting in view of their low cost, renewable plant sources and abundance. ${ }^{18-20}$

Active Carbon ${ }^{8}$, Granular activated carbon ${ }^{21}$, Amberlite IR-120H ${ }^{21}$, activated carbon- with oleic acid as surfactant $^{22}$, Chitosan ${ }^{23}$ and leaves, stems and their ashes of Acacia Melanoxylon and Eichhornia Crassipes ${ }^{24}$, are investigated for Al-removal. Beach cast seaweed ${ }^{25}$ and plant materials of Ficus Racemosa ${ }^{26}$, Cassia Occidentalis ${ }^{27}$, Moryngea Millingtonia ${ }^{28}$ and Cygium Arjunum ${ }^{28}$ are investigated as sorbents. Water hyacinth sorption ability for $\mathrm{Al}^{3+}$ was investigated by growing it in wetlands. ${ }^{29}$

We tried to identify plant materials having $\mathrm{Al}^{3+}$-affinity. Stems of Butea Monosperma and Angle marmelos, are showing $\mathrm{Al}^{3+}$-sorption character. The present research work is related to optimize the

Rasayan J. Chem., 13(4), 2653-2663(2020)

http://dx.doi.org/10.31788/ RJC.2020.1346009 
RASĀYAN J. Chem.

Vol. 13 | No. 4 |2653-2663| October - December | 2020

extraction conditions for the removal of $\mathrm{Al}^{3+}$ using the adsorbents derived from these materials.

\section{Material and Methods \\ Chemicals}

Analytical grade chemicals were used. For the preparation of simulated as well as reagents, double distilled water was used. $500 \mathrm{ppm} \mathrm{Al}^{3+}$ stock solution was prepared. As per the requirement, it was diluted. Eriochrome cyanine R solution, buffer solutions, 5 vol Hydrogen peroxide solution were prepared as described in the literature. ${ }^{30}$

\section{Adsorbents}

Butea monosperma is a dry season quickly growing tree. It belongs to Butea species of the plant kingdom. It grows well in tropical and sub-tropical areas to a height of $15 \mathrm{~m}$. It is a sacred tree for Hindus and its wood pieces are used for fire rituals.

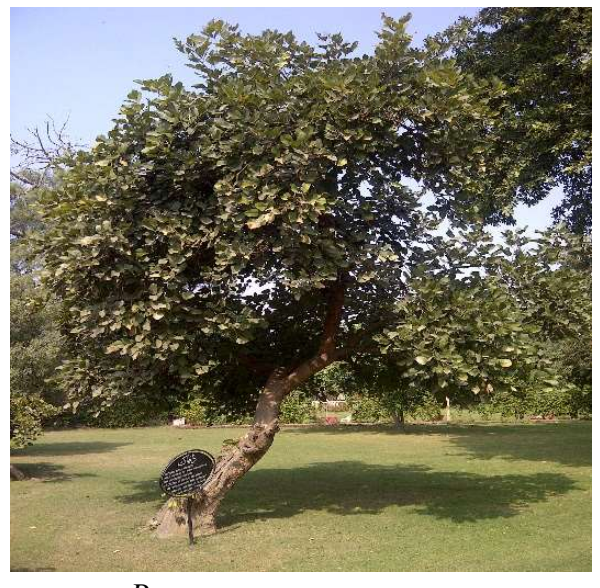

Burea monosperma tree

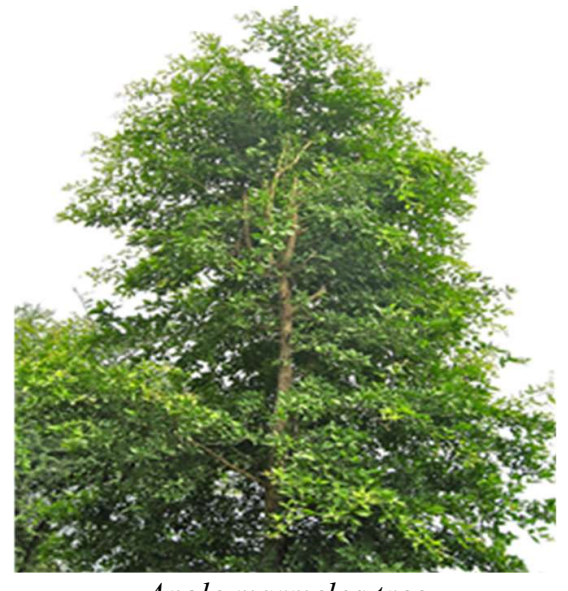

Angle marmelos tree

Fig.-1: Plants showing Strong Adsorption for $\mathrm{Al}^{3+}$ Ions

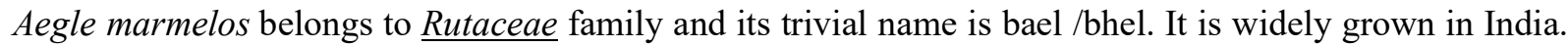
It is a sacred tree for Hindus.

The stems of Burea monosperma tree and Angle marmelos tree were cut into pieces. They were washed with distilled water and dried in Sunlight for one week. Then they were dried at $105^{\circ} \mathrm{C}$ in hot air over for one hour. Then the pieces were crushed to a fine powder and passed through a sieve having pores less than 75 microns in size. Powders were stored in dry bottles. These were investigated as adsorbents. Burea monosperma stem powder was named as: BMSP while Angle marmelos stem powder was named as: AMSP. This terminology is used throughout this manuscript.

\section{Adsorption Experiment}

Batch modes of extraction were employed in the Al-extraction investigations. ${ }^{31,32}$ Synthetic simulated solutions having known $\mathrm{Al}^{3+}$ concentrations were prepared and were subjected to investigations. The general procedure employed was as detailed hereunder.

\section{General Procedure}

$100 \mathrm{ml}$ of simulated $\mathrm{Al}^{3+}$-solutions were taken into stoppered $250 \mathrm{ml}$ bottles. Then known amounts of BMSP or AMSP were added. pHs of solutions were adjusted to desired values with the dropwise addition of diluted solutions of acid or base. Then the bottles were agitated at $300 \mathrm{rpm}$ in Shakers for the required periods. Then the contents in the flash were filtered. The residual amounts of $\mathrm{Al}^{3+}$ in the filtrate were determined using "Eriochrome cyanine R" method as described in Vogel. ${ }^{30}$

The effect of each extraction parameter on $\mathrm{Al}^{3+}$-sorption was investigated by gradually changing the 
RASĀYAN J. Chem.

Vol. 13 | No. 4 |2653-2663| October - December | 2020

magnitude of the targeted character but keeping constant the other parameters. The findings are depicted in Fig.-2 to 11 and Tables- 1 and 2.

After establishing extraction conditions at optimum values, interference of two-fold excess of co-ions was investigated using simulated solutions. Regeneration as well as applications were also investigated. Results are noted in Fig.-12 and 13.

\section{RESULTS AND DISCUSSION}

BMSP and AMSP were evaluated as adsorbents for the extraction of $\mathrm{Al}^{3+}$ ions from water. The investigations were performed to optimize different extraction conditions to develop maximum affinity between $\mathrm{Al}^{3+}$ and the sorbents. The findings are as follows.

\section{Equilibration Time}

The minimum equilibration time needed for the maximum extraction of $\mathrm{Al}^{3+}$, is assessed. For this, known amounts of BMSP /AMSP were added to $50 \mathrm{ppm} \mathrm{Al}^{3+}$ solution. Then the $\mathrm{pH}$ was adjusted to 8 using dil $\mathrm{HCl}$ or $\mathrm{NaOH}$. Then the solutions were shaken at $300 \mathrm{rpm}$ for different time intervals. Then the solution was fileted and the filtrate was analyzed for residual $\mathrm{Al}^{3+}$. The findings are plotted in Fig.-2 and 3.

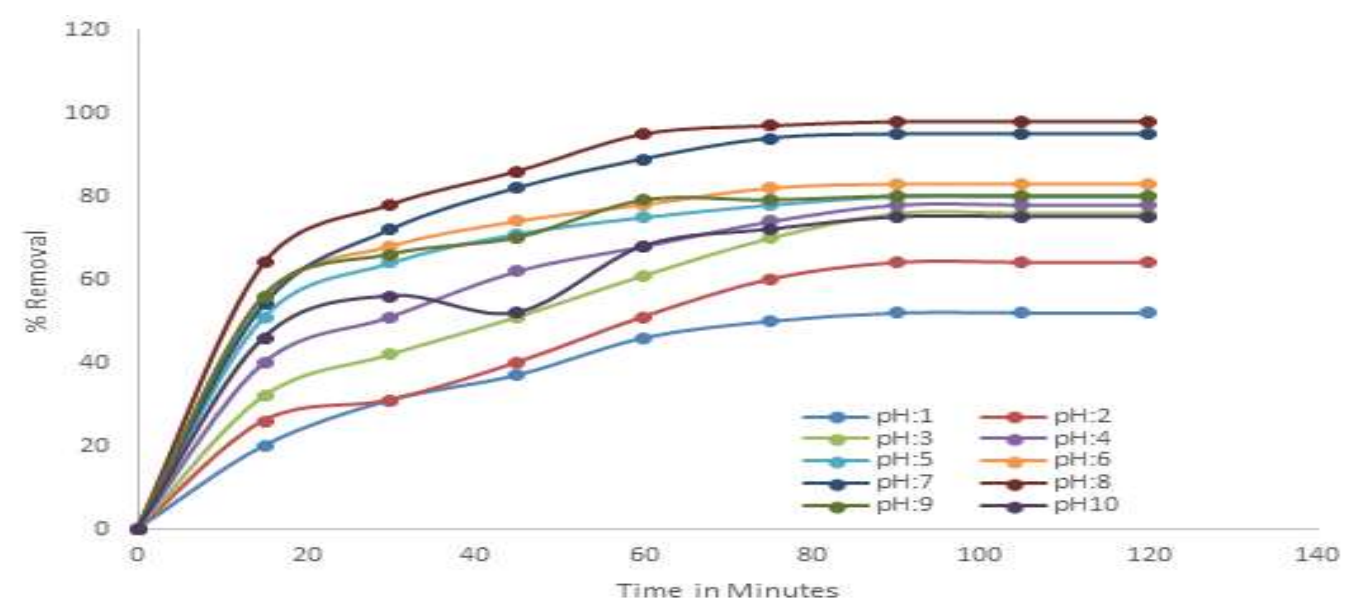

Fig.-2: BMSP: Time Vs \% Removal of $\mathrm{Al}^{3+}\left(\mathrm{Al}^{3+}\right.$ Conc.: 75 ppm; BMSP :0.150g/100 ml)

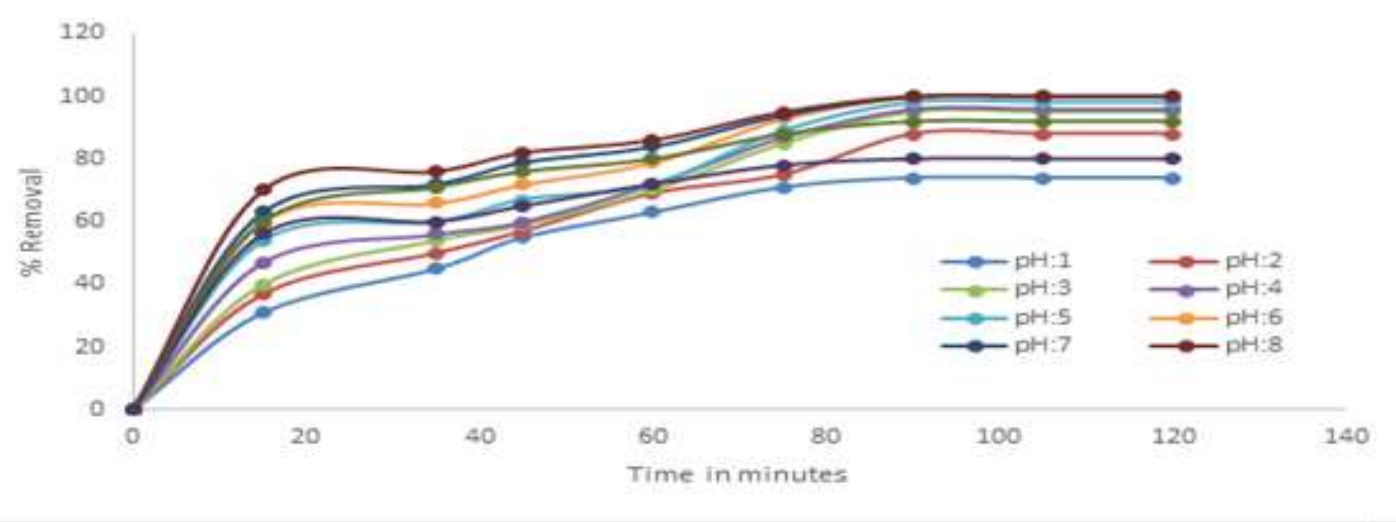

Fig.-3: AMSP: Time Vs Removal of $\mathrm{Al}^{3+}\left(\mathrm{Al}^{3+}\right.$ Conc. : 75 ppm; AMSP: $\left.0.125 \mathrm{~g} / 100 \mathrm{ml}\right)$

With the rise in time, $\%$ removal of $\mathrm{Al}^{3+}$ is increased for both the adsorbents at all initial pHs. Initially, the rate of adsorption is more and it decreases with time. After a certain time, almost a study state is reached with a further marginal increase in adsorption. With 15 minutes of equilibration and at $\mathrm{pH}: 8,64.0 \%$ and 
RASĀYAN J. Chem.

Vol. 13 | No. 4 |2653-2663| October - December | 2020

$70.0 \%$ of $\mathrm{Al}^{3+}$ were removed from $100 \mathrm{ml}$ of $75 \mathrm{ppm} \mathrm{Al}^{3+}$ solution with BMSP and AMSP respectively as adsorbents. A time of 90 min has been taken to achieve $98.0 \%$ removal with BMSP and $100.0 \%$ with AMSP. Further, as is seen from the curves, the equilibration time needed to reach the study state also depends upon the initial $\mathrm{pH}$. The equilibration time decreases with a rise in $\mathrm{pH}$.

For a fixed amount of adsorbent, the active sites are limited. Initially, the number of active sites available is more and so, the rate of adsorption is more. With the lapse of time, the active sites are used up or engaged with adsorbate, $\mathrm{Al}^{3+}$. So, the rate of adsorption of $\mathrm{Al}^{3+}$ falls. A study state is reached when all the active sites are practically used up.

\section{Effect of pH}

The initial $\mathrm{pH}$ effect on the extraction of $\mathrm{Al}^{3+}$ was investigated by varying the $\mathrm{pH}$ from 2 to 10 while maintaining all other extraction conditions at constant levels. The results are presented in Fig.-4. pHzpc was evaluated from the Fig.-5.

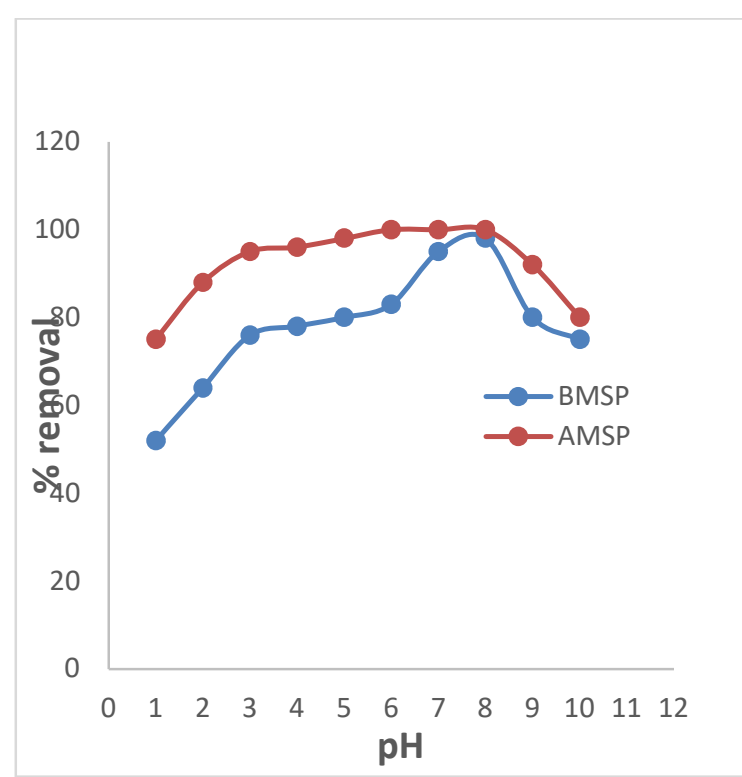

Fig.-4: pH Vs \% Al(III) Removal

$\left(\mathrm{Al}^{3+}\right.$ Conc. : 75 ppm;BMSP: $0.15 \mathrm{~g} / 100 \mathrm{ml}$ or AMSP: $0.125 \mathrm{~g} / 100 \mathrm{ml}$ )

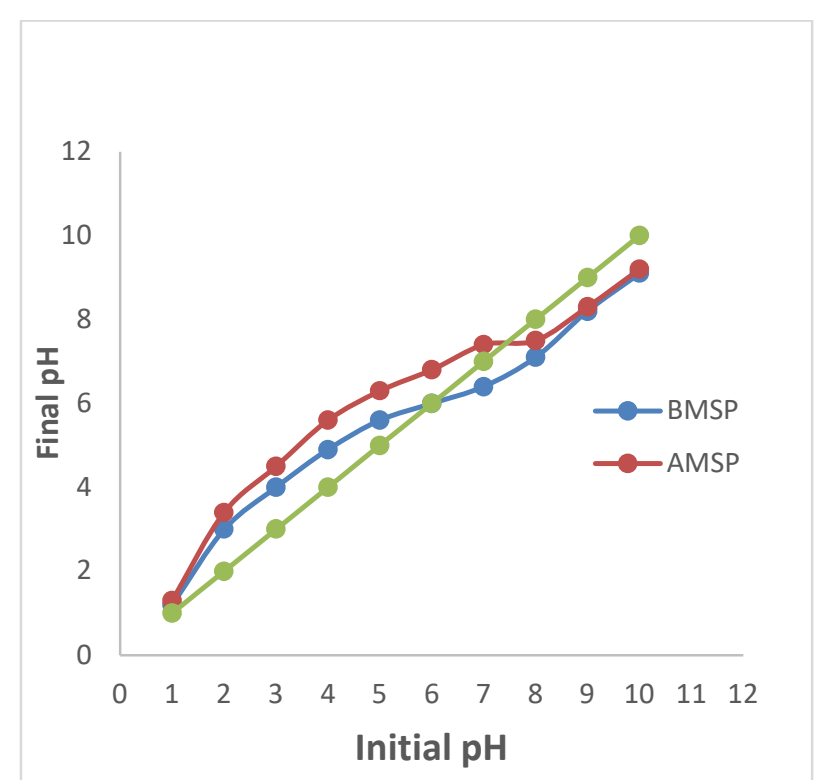

Fig.-5: pHzpc Evaluation for BMSP and AMSP

It is interesting to note that substantial amounts of $\mathrm{Al}^{3+}$ are removed in a wide range of pHs: 3 to 9 . With BMSP, $76.0 \%$ at $\mathrm{pH} ; 3$ to $98.0 \%$ at 8 and with AMSP $95 \%$ at $\mathrm{pH}: 3$ to $100.0 \%$ at $\mathrm{pH}: 8$. The maximum extraction is noted at $\mathrm{pH}: 8$. Above this $\mathrm{pH}$, the sorption is less favoured and so $\%$ removal falls.

pHzpc values for BMSP and AMSP are 6.3 and 7.3 respectively. Above these values, the surface of the said sorbents acquires a negative charge. It is due to the dissociation of functional groups. Below this $\mathrm{pHzpc}$, the dissociation is less probable; even protonation occurs at low $\mathrm{pHs}$.

At low $\mathrm{pH}$ values, $\mathrm{Al}$ (III) exists as $\mathrm{Al}\left[\left(\mathrm{H}_{2} \mathrm{O}\right)_{6}\right]^{3+}$. With raise in $\mathrm{pH}, \mathrm{Al}(\mathrm{OH})^{2+}$ and $\mathrm{Al}(\mathrm{OH})_{2}{ }^{+}$are increasingly formed $^{33}$. In neutral conditions amorphous $\mathrm{Al}(\mathrm{OH})_{3}$ is nucleated. In basic conditions, the aggregates dissolve to form $\mathrm{Al}(\mathrm{OH})^{4-}$. Between $\mathrm{pH}: 6$ to 8 , hydrated $\mathrm{Al}(\mathrm{OH})_{3}$ nucleates are not precipitated as their formation from $\mathrm{Al}(\mathrm{OH})_{2}{ }^{+}$is inhibited. ${ }^{33}$

The good affinity of $\mathrm{Al}^{3+}$ at low pHs, indicates binding between Al-species and functional groups of sorbents: $-\mathrm{OH} / \mathrm{COOH}$, which are not dissociated as is reflected from $\mathrm{pHzpc}$ values. Due to negative charges on the sorbent surface and $\mathrm{Al}$ (III) species, they get repelled. Hence fall of adsorption at high pHs.

\section{AMSP/ BMSP Concentrations}

The minimum AMSP/ BMSP Concentration required for $\mathrm{Al}^{3+}$ removal was investigated. By changing the AMSP/BMSP concentration but maintain the other extraction conditions at constant levels, $\%$ removal of 
RASĀYAN J. Chem.

Vol. 13 | No. 4 |2653-2663| October - December | 2020

$\mathrm{Al}^{3+}$ was assessed. The results are depicted in Fig.-6. $1.25 \mathrm{~g} / \mathrm{L}$ for AMSP and 1.5g/ L for BMSP are minimum needed for removing completely $\mathrm{Al}^{3+}$ from a solution of conc. $75 \mathrm{ppm}$.

As is evident from the Fig that initially, \% removal of $\mathrm{Al}^{3+}$ is linearly increased with the increase in conc. of AMSP/BMSP. But after a certain concentration, $\%$ removal is reduced and linearity is lost. Further after $1.25 \mathrm{~g} / 1$ for AMSP and $1.50 \mathrm{~g} / 1$ for BMSP, study states are reached.

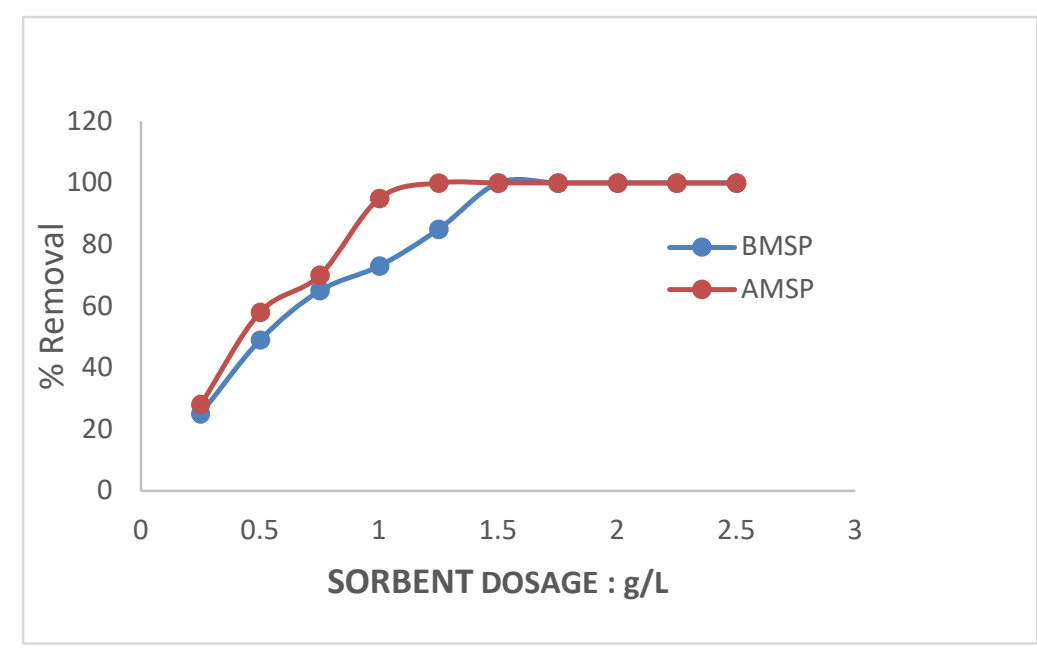

Fig.-6: Sorbent Dosage Vs \% Removal $\mathrm{Al}^{3+}\left(\mathrm{Al}^{3+}: 75\right.$ ppm; $\mathrm{pH}: 8$; Time: $\left.90 \mathrm{~min}\right)$

\section{Initial Concentration of $\mathrm{Al}^{3+}$}

The effect of initial conc. of $\mathrm{Al}^{3+}$ on the adsorption capacity of AMSP and BMSP was investigated. For this $100 \mathrm{ml}$ of different concentrations: $25 \mathrm{ppm}$ to $200 \mathrm{ppm}$ of $\mathrm{Al}^{3+}$ were equilibrated with $0.125 \mathrm{~g} / 100 \mathrm{ml}$ of AMSP or $0.150 \mathrm{~g} / 100 \mathrm{ml}$ of BNSP at $\mathrm{pH}: 8$ for 90 minutes. The solutions were filtered. Residual $\mathrm{Al}^{3+}$ was estimated. The results are plotted in Fig.-7 and 8.

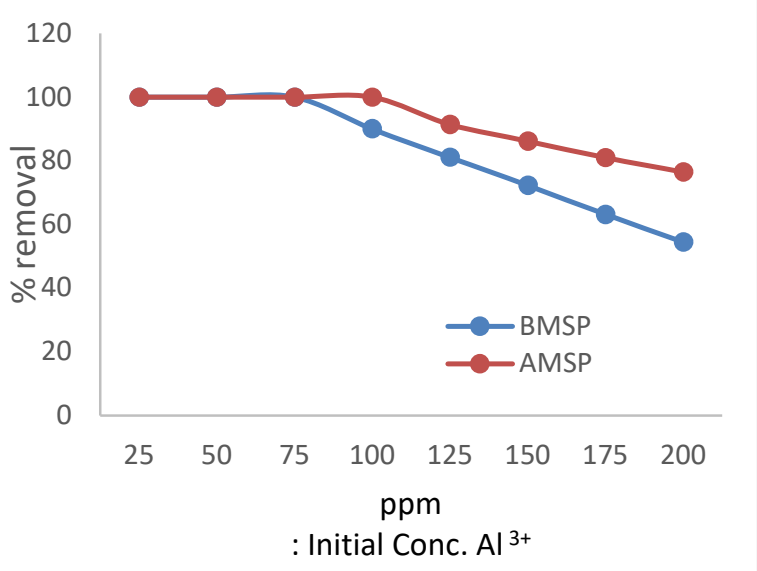

Fig.- 7: Initial Concentration Vs \% Removal

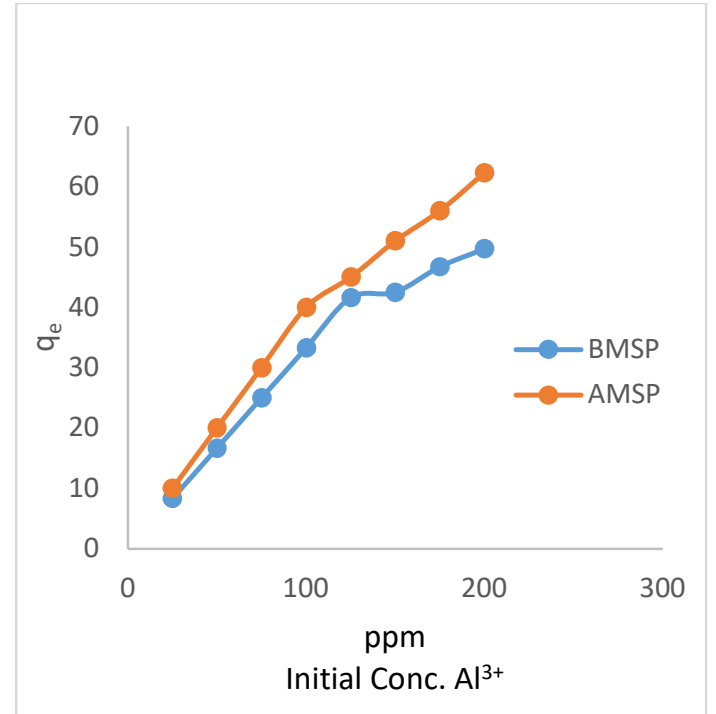

Fig.- 8: Adsorption Capacity Vs Initial Concentration

With the increase in the concentration of $\mathrm{Al}^{3+}$, more $\mathrm{Al}^{3+}$ ions are drifted towards the surface of the adsorbents due to diffusion and so, adsorption capacity (in taking capacity), is increased. But for a fixed amount of adsorbent, the active sites are limited and the needed number of sites proportional to the increase in concentration, are not available. Hence, a decrease in $\%$ removal. 
RASĀYAN J. Chem.

Vol. 13 | No. 4 |2653-2663| October - December | 2020

\section{Temperature Effect}

The effect of temperature on the adsorption abilities of BMSP and AMSP towards $\mathrm{Al}^{3+}$ was investigated at temperatures: 303,313 and $323 \mathrm{~K}$. The results were depicted by plotting as $\ln \mathrm{K}_{\mathrm{d}} \mathrm{Vs}_{\mathrm{s}} 1 / \mathrm{T}$, Fig.-9a and b ${ }^{34,35}$

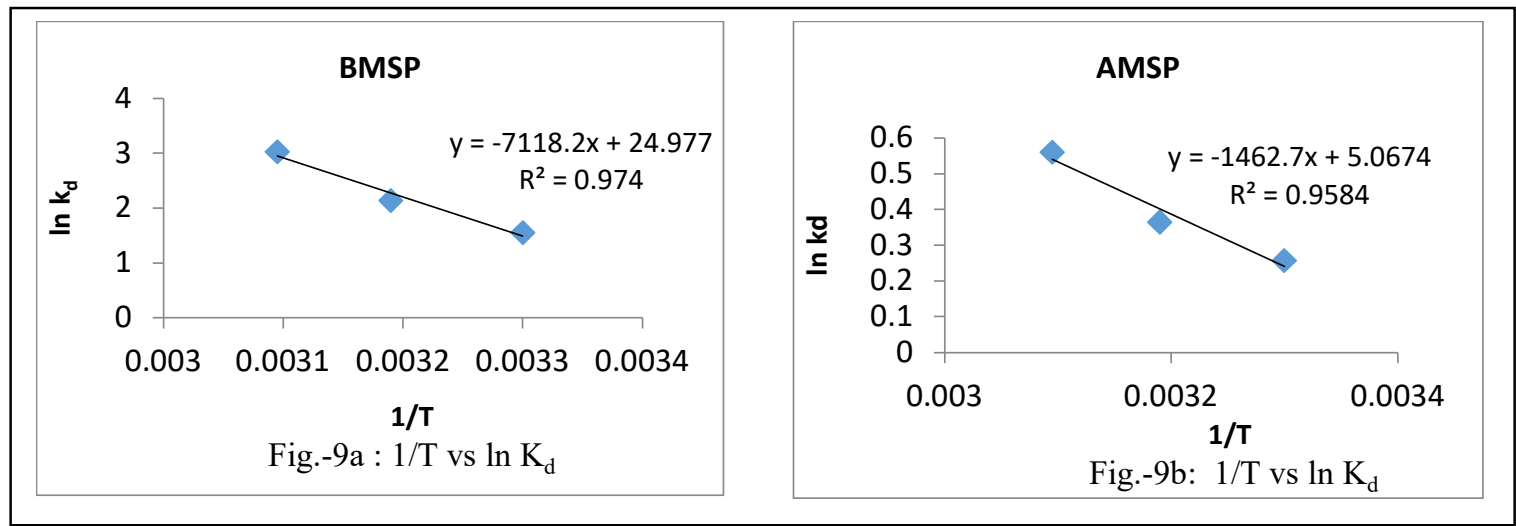

Thermodynamic parameters: free energy: $\Delta \mathrm{G}$, ; change in enthalpy, $\Delta \mathrm{H}$ and change in entropy $\Delta \mathrm{S}$, were evaluated employing the equations: $\Delta \mathrm{G}=-\mathrm{RT} \ln \mathrm{K}_{\mathrm{d}} ; \ln \mathrm{K}_{\mathrm{d}}=\Delta \mathrm{S} / \mathrm{R}-\Delta \mathrm{H} / \mathrm{RT} ; \quad \mathrm{K}_{\mathrm{d}}=\mathrm{q}_{\mathrm{e}} / \mathrm{C}_{\mathrm{e}} \quad \& \quad \Delta \mathrm{G}=\Delta \mathrm{H}$ $-\mathrm{T} \Delta \mathrm{S}$, where $\mathrm{K}_{\mathrm{d}}=$ distribution coefficient, $\mathrm{q}_{\mathrm{e}}=$ amount of adsorbed $\mathrm{Al}^{3+}, \mathrm{C}_{\mathrm{e}}=$ Equilibrium conc. of $\mathrm{Al}^{3+}, \mathrm{T}=$ Temp. in $\mathrm{K}, \mathrm{R}=$ gas constant. ${ }^{36,37}$ The values are tabulated in Table-1.

The positive values of $\Delta \mathrm{H}$ indicate the endothermic process of sorption. $\mathrm{R}^{2}$ values confirm the same. Positive $\Delta \mathrm{S}$ values signify the disorderliness at a solid-liquid interface with a raise in temperature. Negative $\Delta \mathrm{G}$ values indicate that the adsorption is spontaneous.

\section{Adsorption Isotherms}

The sorption nature of BMSP and AMSP towards $\mathrm{Al}^{3+}$ was analyzed using Freundlich ${ }^{38,39}$ and Langmuir isotherms ${ }^{40,41}$ Linear forms of Freundlich Isotherm $: \log \left(\mathrm{q}_{\mathrm{e}}\right)=\log \mathrm{k}_{\mathrm{f}}+\left(\frac{1}{n}\right) \log \mathrm{C}_{\mathrm{e}}$ and Langmuir Isotherm: $\left.\mathrm{C}_{\mathrm{e}} / \mathrm{q}_{\mathrm{e}}\right)=\left(\mathrm{a}_{\mathrm{L}} / \mathrm{k}_{\mathrm{L}}\right) \mathrm{Ce}+1 / \mathrm{k}_{\mathrm{L}}$ were used. The relating plots are depicted in Fig.-10 and 11.

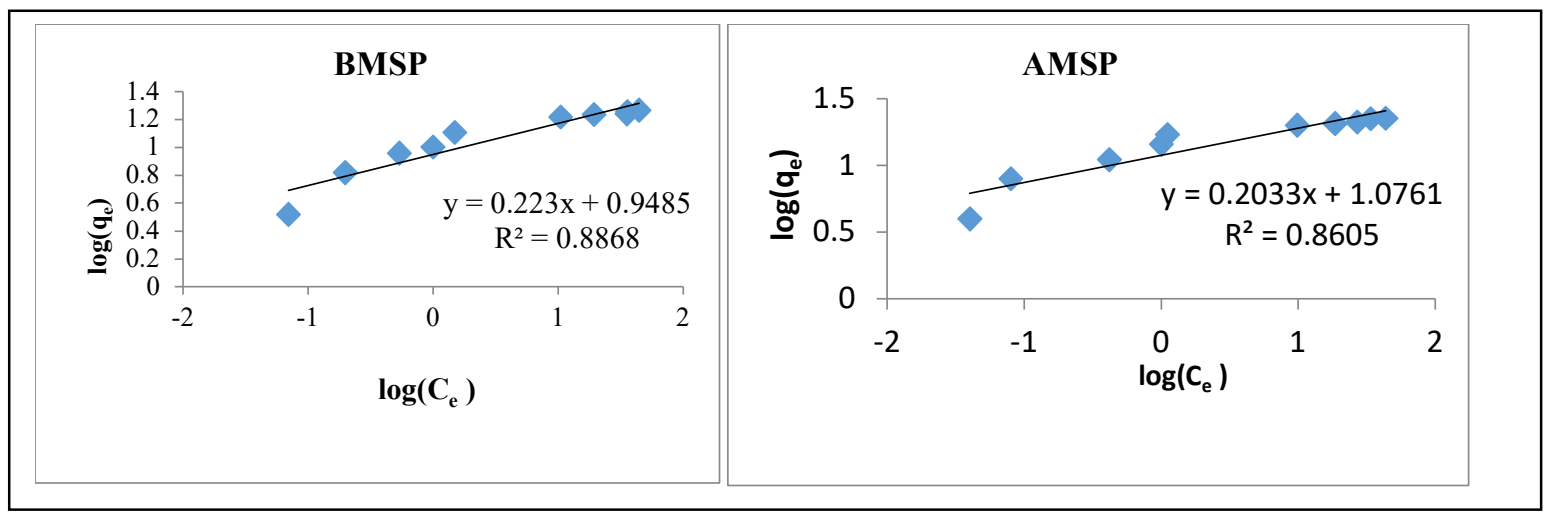

Fig.-10: Freundlich Isotherms

It can be inferred from the plots that the Correlation coefficient, $\mathrm{R}^{2}$, values are more for Langmuir isotherms: 0.9985 for BMSP and 0.9938 for AMSP than Freundlich isotherms: 0.8868 for BMSP and 0.8605 for AMSP. So Langmuir isotherms describe well the adsorption on both the adsorbents. This indicates homogenous surfaces of BMSP and AMSP and also monolayer adsorption.

Table-1: Thermodynamic Parameters: for $\mathrm{Al}^{3+}$ Ion Adsorption onto BMSP \& AMSP

\begin{tabular}{c|c|c|c|c|c|c}
\hline & $\Delta \mathrm{H}, \mathrm{kJ} / \mathrm{mol}$ & $\Delta \mathrm{S}, \mathrm{J} / \mathrm{mol} / \mathrm{K}$ & \multicolumn{3}{|c|}{$\Delta \mathrm{G}, \mathrm{kJ} / \mathrm{mol}$} & $\mathrm{R}^{2}$ \\
\hline Temp. $(\mathrm{K})$ & & & 303 & 313 & 323 & \\
\hline BMSP & 59.19 & 206.9 & -3.713 & -4.859 & -7.875 & 0.974 \\
\hline AMSP & 12.10 & 41.90 & -0.606 & -1.027 & -1.448 & 0.958 \\
\hline
\end{tabular}


RASĀYAN J. Chem.

Vol. 13 | No. 4 |2653-2663| October - December | 2020

\section{Kinetics of Adsorption Process}

Kinetics of adsorption was analysed by various standard models. The equations used are: pseudo first-order: $\log \left(\mathrm{q}_{\mathrm{e}}-\mathrm{q}_{\mathrm{t}}\right)=\log \mathrm{q}_{\mathrm{e}}-\mathrm{k}_{1} \mathrm{t} / 2.303^{41,42} ;$ pseudo second-order $=\mathrm{t} / \mathrm{q}_{\mathrm{t}}=1 / \mathrm{k}_{2} q_{e}^{2}-\left(1 / \mathrm{q}_{\mathrm{e}}\right) \mathrm{t}^{42}$, 43; Weber and Morris

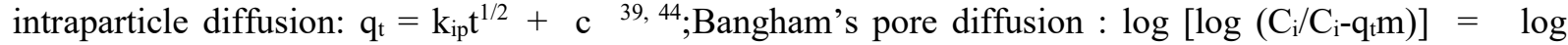
$\left(\mathrm{k}_{\mathrm{o}} / 2.303 \mathrm{~V}\right)+\alpha \log (\mathrm{t}){ }^{36,39,45}$; Elovich equation: $\mathrm{q}_{\mathrm{t}}=1 / \beta \ln (\alpha \beta)+1 / \beta \ln (\mathrm{t}){ }^{36,37,46,47}$ The pertaining values are presented in Table-2.

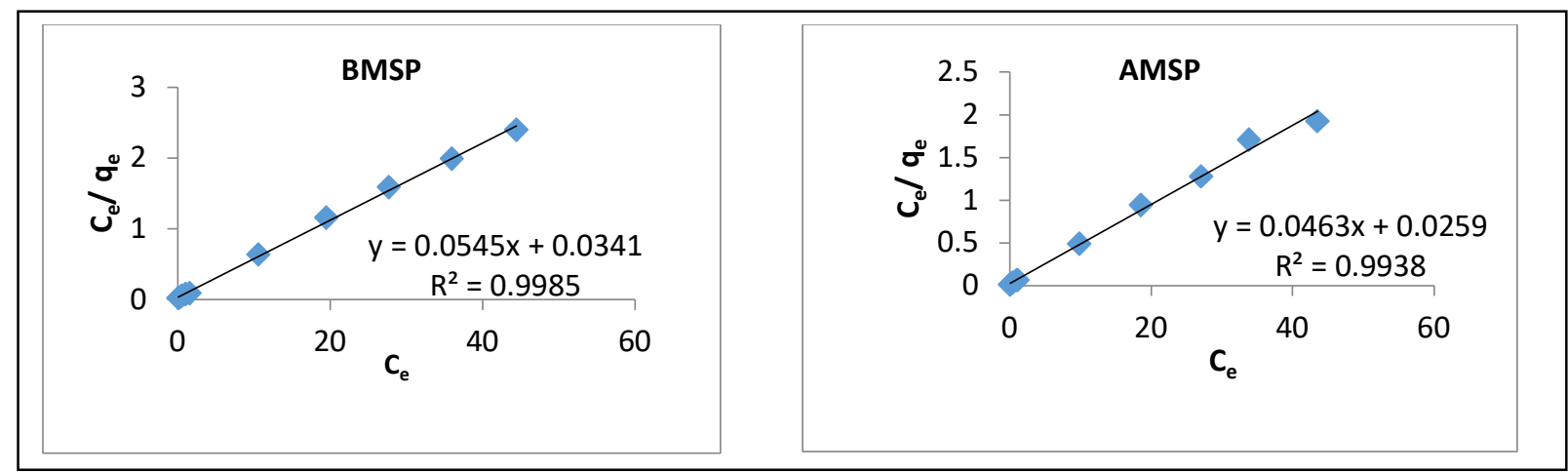

Fig.-11: Langmuir Isotherms

Table-2: Kinetics of Adsorption: Various Characteristics

\begin{tabular}{|c|c|c|c|c|}
\hline S. No. & Sorbent & Slope & Intercept & $\mathrm{R}^{2}$ \\
\hline 1 & \multicolumn{4}{|c|}{ Pseudo First-order } \\
\hline & BMSP & -0.0078 & 0.7053 & 0.9788 \\
\hline & AMSP & -0.0102 & 0.7822 & 0.9808 \\
\hline 2 & \multicolumn{4}{|c|}{ Pseudo Second-order } \\
\hline & BMSP & 0.0664 & 0.6734 & 0.9900 \\
\hline & AMSP & 0.0389 & 0.2060 & 0.9925 \\
\hline 3 & \multicolumn{4}{|c|}{ Weber-Mories Intra Particle Diffusion Model } \\
\hline & BMSP & 0.3552 & 10.760 & 0.8668 \\
\hline & AMSP & 0.3243 & 15.56 & 0.8456 \\
\hline 4 & \multicolumn{4}{|c|}{ Bangham's pore Diffusion } \\
\hline & BMSP & 0.7001 & -1.3112 & 0.9301 \\
\hline & AMSP & 0.6224 & -1.0788 & 0.9623 \\
\hline 5 & \multicolumn{4}{|c|}{ Elovich Model } \\
\hline & BMSP & 1.9760 & 6.3454 & 0.9701 \\
\hline & AMSP & 1.4320 & 12.90 & 0.9569 \\
\hline
\end{tabular}

Among the five models studied, Pseud Pseudo second-order has higher $\mathrm{R}^{2}$ values for both the adsorbents: BMSP and AMSP. Hence, Pseudo second-order describes well the kinetics process.

\section{Interfering Ions}

Possible Interference caused by commonly co-existing cations and anions in water is one of the aspects of the investigation. So in the present study synthetic simulated solutions of $75 \mathrm{ppm}$ of $\mathrm{Al}^{3+}$ having two-fold excess of targeted co-ions were prepared. They were subjected to extraction at the optimum condition of $\mathrm{pH}: 8$, time of equilibration: $90 \mathrm{~min}$, sorbent dosage of: $0.125 \mathrm{~g} / 100 \mathrm{ml}$ for AMSP and $0.150 \mathrm{~g} / 100 \mathrm{ml}$ for BMSP, $300 \mathrm{rpm}$ and at $303 \mathrm{~K}$. The results are noted in Fig.-12. It may be seen that anions (except fluoride) and cations have marginally interfered with the extraction procedures developed in this work with AMSP and BMSP.

\section{Regeneration of Spent AMSP AND BMSP}

To make the process cost-effective, the spent adsorbents were tried to be regenerated for subsequent use. Various eluents were investigated for this purpose. $0.1 \mathrm{~N} \mathrm{NaOH}$ solution was found to be effective. The 
RASĀYAN J. Chem.

Vol. 13 | No. 4 |2653-2663| October - December | 2020

loss of adsorption ability for the removal $\mathrm{Al}^{3+}$ with each successive regeneration was investigated as per the method developed. The results are furnished in Fig.-13.

It may be noted that until three cycles of regenerations, AMSP, as well as BMSP, retained their sorption ability with marginal loss.

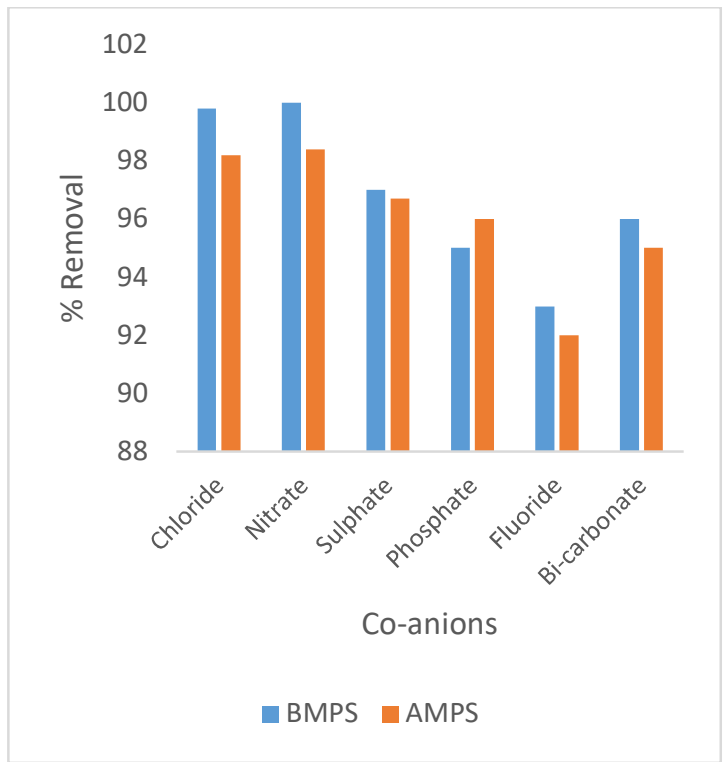

Fig.-12a: Interference of Co-anions

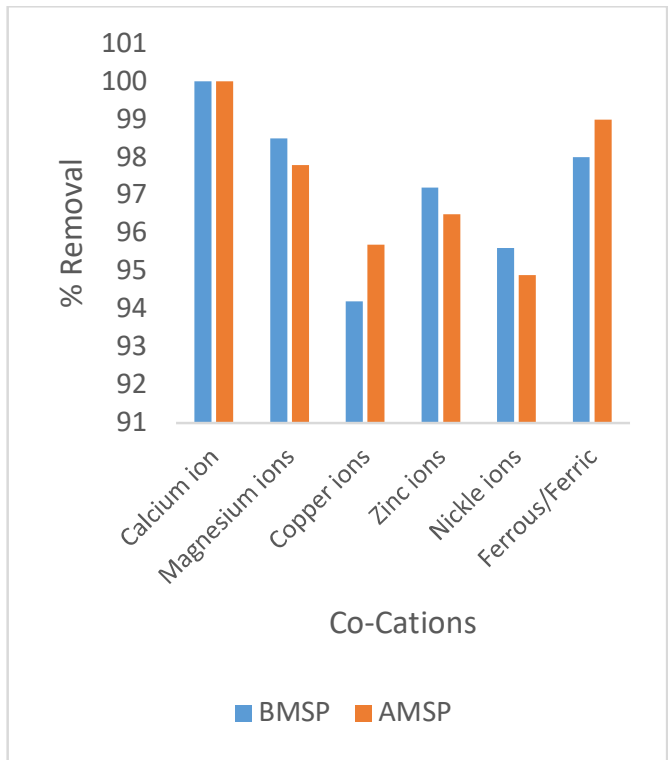

Fig.-12b: Interference of Co-Cations

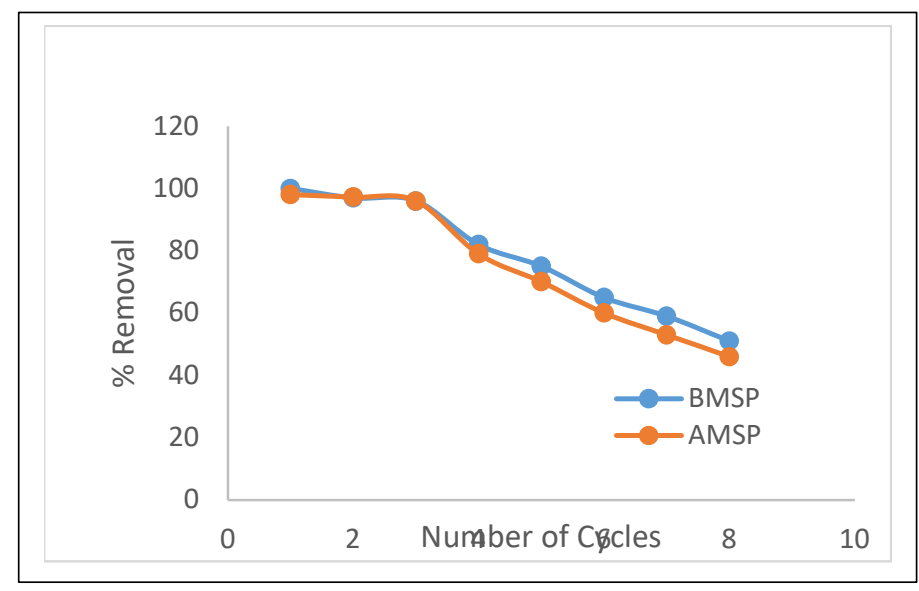

\section{Comparison with Previous Works}

Fig.-13: Regeneration and Reuse

The merits of BMSP and AMSP are compared with the existing sorbents. A comparative statement is presented in Table-3.

It can be seen from the Table that BMSP and AMSP have more adsorption capacity than many of the reported adsorbents. Further, these are effective in a wide pH range: 3 to 9 and are applicable even in fair acidic solutions besides neutral and faintly basic solutions.

Table-3: Adsorption Capacities Comparison

\begin{tabular}{c|c|c|c|c|l}
\hline S. No. & Adsorbent & $\mathrm{pH}$ & $\begin{array}{c}\text { Ci. Of Cr(VI) } \\
\text { (in ppm) }\end{array}$ & $\begin{array}{c}\text { Adsorption } \\
\text { Capacity } / \% \\
\text { Removal }\end{array}$ & References \\
\hline 1 & Activated carbon & $4-8$ & 3 & $10 \mathrm{mg} / \mathrm{g}$ & 3 \\
\hline
\end{tabular}


RASĀYAN J. Chem.

Vol. 13 | No. 4 |2653-2663| October - December | 2020

\begin{tabular}{|c|c|c|c|c|c|}
\hline 2 & $\begin{array}{c}\text { Modified activated } \\
\text { carbon as a sorbent and } \\
\text { oleic acid as surfactant }\end{array}$ & 7 & 1.35 & $100 \%$ removal & 22 \\
\hline 3 & Chitosan & 4 & $5-40$ & $49.0 \mathrm{mg} / \mathrm{g}$ & 23 \\
\hline 4 & $\begin{array}{c}\text { Acacia Melanoxylon } \\
\text { and } \\
\text { Eichhornia Crassipes }\end{array}$ & 6 & 50 & $\begin{array}{c}20 \mathrm{mg} / \mathrm{g} \text { (stems) } \\
\text { and } \\
25 \mathrm{mg} / \mathrm{g} \text { (stems) }\end{array}$ & 24 \\
\hline \multirow[t]{2}{*}{5} & $\begin{array}{l}\text { Moryngea Millingtonia } \\
\text { Leaves and their ash }\end{array}$ & 6 & 50 & $\begin{array}{l}16.7 \mathrm{mg} / \mathrm{g} \text { for } \\
\text { leaves } 20.0 \mathrm{mg} / \mathrm{gl} \\
\text { for ashes }\end{array}$ & \multirow[b]{2}{*}{28} \\
\hline & $\begin{array}{l}\text { Cygium Arjunum: } \\
\text { Barks and their ash }\end{array}$ & 6 & 50 & $\begin{array}{c}14.8 \text { for barks and } \\
20.5 \text { for their ash }\end{array}$ & \\
\hline 6 & Ficus Racemosa Plants & 6 & 50 & $25.0 \mathrm{mg} / \mathrm{g}$ & 26 \\
\hline 7 & Cassia Occidentalis & $6-8$ & 50 & $26.0 \mathrm{mg} / \mathrm{g}$ & 27 \\
\hline 8 & $\begin{array}{l}\text { Refused beach cast } \\
\text { seaweed }\end{array}$ & 4 & 10 to 100 & $22.5 \mathrm{mg} g(-1)$ & 25 \\
\hline 9 & $\begin{array}{c}\text { Granular activated } \\
\text { carbon and } \\
\text { Amberlite IR-120H }\end{array}$ & 5 & 100 & 99.2 and $99.55 \%$ & 21 \\
\hline 9 & BMSP & $\begin{array}{c}3-9 \\
\text { Maximus at:8 }\end{array}$ & 75 & $\begin{array}{c}100 \% \text { Removal } \\
50 \mathrm{mg} / \mathrm{g}\end{array}$ & \multirow[t]{2}{*}{$\begin{array}{l}\text { PRESENT } \\
\text { WOK }\end{array}$} \\
\hline 10 & AMSP & $\begin{array}{c}3-9 \\
\text { Maximus at:8 }\end{array}$ & 75 & $\begin{array}{c}100 \% \text { Removal } \\
62.0 \mathrm{mg} / \mathrm{g}\end{array}$ & \\
\hline
\end{tabular}

\section{Applications}

BMSP and AMSP effectiveness as adsorbents in treating $\mathrm{Al}^{3+}$ contaminated real water samples were investigated. Samples from Al-based industries and polluted lake waters were collected. The amounts of $\mathrm{Al}^{3+}$ present were estimated. In the case of lake waters, only traces of $\mathrm{Al}^{3+}$ was present. Hence, known amounts of $\mathrm{Al}^{3+}$ were added to them. Then the samples were treated with BMSP $(0.150 \mathrm{~g} / 100 \mathrm{ml})$ and AMSP $(0.125 \mathrm{~g} / 100 \mathrm{ml})$ at $\mathrm{pH}: 8$ for 90 minutes at $303 \mathrm{~K}$ and $300 \mathrm{rpm}$. The solutions were filtered and the filtrates were estimated for $\mathrm{Al}^{3+}$. The findings were enlisted in Table-4.

Table-4: Applications: $\mathrm{Al}^{3+}$ Removal

(pH:8, Sorbent Dosage: $0.125 \mathrm{~g} / 100 \mathrm{ml}$ for AMSP and 0.150 g/100 ml for BMSP; Time:90 min, rpm:300 , Temperature: $303 \mathrm{~K}$ )

\begin{tabular}{c|c|c|c}
\hline Samples & $\mathrm{Ci}^{*}$ & $\mathrm{Ce}^{*}$ & \% Removal \\
\hline \multicolumn{4}{c}{ Al-based Industries } \\
\hline 2 & $9.5 \mathrm{ppm}$ & Zero & $100 \%$ \\
3 & $12.6 \mathrm{ppm}$ & Zero & $100 \%$ \\
1 & $18.0 \mathrm{ppm}$ & Zero & $100 \%$ \\
\hline \multicolumn{4}{c}{ Lake Samples -fed with known Amounts of $\mathrm{Al}^{3+}$} \\
1 & $15.0 \mathrm{ppm}$ & Zero & $100 \%$ \\
2 & $20.0 \mathrm{ppm}$ & Zero & $100 \%$ \\
3 & $30.0 \mathrm{ppm}$ & Zero & $100 \%$ \\
\hline Ci* and Ce* are the initial and final concentration of Cr(VI); \\
The values are average of 3 samples: Standard Deviation: $0.05 \%$ \\
\hline
\end{tabular}

It can be inferred from the data that BMSP and AMSP are very effective in the removal of $\mathrm{Al}^{3+}$.

\section{CONCLUSION}

- Sorbents derived from stems of Burea monosperma (BMSP) and Angle marmelos (AMSP) are found to be very effective in the removal of $\mathrm{Al}^{3+}$ from water.

- Extraction conditions are optimized. At $\mathrm{pH}: 8$, both the adsorbents ( $0.150 \mathrm{~g} / 100 \mathrm{ml}$ of BMSP or 0.125 $\mathrm{g} / 100 \mathrm{ml}$ of AMSP), remove completely $\mathrm{Al}^{3+}$ from $100 \mathrm{ml}$ of $75 \mathrm{ppm}$ solution of $\mathrm{Al}^{3+}$ after an equilibration time of 90 minutes at room temp:303 $\mathrm{K}$ and $300 \mathrm{rpm}$. 
RASĀYAN J. Chem.

Vol. 13 | No. 4 |2653-2663| October - December | 2020

- Adsorption capacities are as high as: $50.0 \mathrm{mg} / \mathrm{g}$ for BMSP and $62.0 \mathrm{mg} / \mathrm{g}$ for AMSP.

- Good extractions are observed in a wide range of $\mathrm{pH}: 3$ to 9 with a maximum at $\mathrm{pH}: 8$ for both the sorbents. This facilitates the applications of these sorbents even for acidic waters beside their applications for neutral and slightly basic solutions

- Interference studies reveal the common co-ions interfere, is marginal.

- Thermodynamic parameters are evaluated and they emphasize the spontaneity of sorption of $\mathrm{Al}^{3+}$ onto BMSP and AMSP.

- The application of adsorption isotherms supports Langmuir's mode of adsorption.

- Of the various kinetic models applied for adsorption, pseudo-second-order fits well.

- Spent BMSP, as well as AMSP, can be regenerated and reused until three cycles with marginal loss of sorption capacities.

- BMSP and AMSP are successfully applied to remove completely $\mathrm{Al}^{3+}$ from the samples of industrial effluents as well as polluted lakes.

\section{REFERENCES}

1. Irene R. Campbell, Lloyd B. Tepper and Robert D. Lingg, Aluminum in the Environment and Human Health, 8, 3(1974), DOI:10.1289/ehp.7483

2. W.L.Lindsay, Walthal, The Environmental Chemistry of Aluminum, Ed. G Sposito, $2^{\text {nd }}$ Ed., CRC Press, Boca Raton, Florida, p. 334 (1996).

3. Parisa Ghashghaiee Pour, Mohammad Ali Takass and Touba Hamoule, Oriental Journal of Chemistry, 30(3), 1365(2014), DOI:10.13005/ojc/300356

4. T. P. Flaten, A.C. Alfrey, J.D. Brichall, J. Savory and R.A. Yokel, Journal of Toxicology and Environmental Health, 48, 525(1996).

5. J. Desccotes, Immune-Toxicology of Drugs and Chemicals, Elsevier, Amsterdam (1988)

6. J. McClure and P. S. Smith, The Journal of Pathology, 142, 293(1984). DOI: 10.1002/path.1711420407

7. J.D. Birchall, C. Exley, J.S. Chappell and M.J. Phillips, Nature (London), 46, 338(1989).

8. K.E. Haven, Canadian Journal of Fisheries and Aquatic Sciences, 49(11), 2392(1992), DOI: $10.1139 / \mathrm{f} 92-264$

9. R.W. Gensemer, Limnology and Oceanography, 36(1), 123(1991), DOI:10.4319/1o.1991.36.1.0123

10. D.R. Parker, T B Kinraide, L and W. Zelazny, Soil Science Society of America Journal, 53, 789(1989), DOI: 10.2136/sssaj1989.03615995005300030027x

11. M. Pesavento, G. Alberti and R. Bieuz, Analitica Chimica Acta, 367(1-3), 215(1998).

12. R. Asrarian, R. Jadidian, H. Parham and S. Haghtalab, Advanced Materials Research, 829,752(2013), DOI:10.4028/www.scientific.net/amr.829.752

13. P. Matus and J. Kubova, Journal of Inorganic Biochemistry, 99, 1769(2005),

14. T.S. Singh and K.K. Pant, Separation and Purification Technology, 36(2), 139(2004), DOI: 10.1016/S1383-5866(03)00209-0

15. Razieh Asrarian, Reza Jadidian, Hooshang Parham, Sara Haghtalab, Advanced Materials Research , 829, 752(2013), DOI:10.4028/www.scientific.net/AMR.829.752

16. Mouna Cherifi, Sabir Hazourli, Steeve Pontvianne, François Lapicque and Jean-Pierre Leclerc, Desalination and Water Treatment, 57 (39), 18500(2015), DOI:10.1080/19443994.2015.1094427

17. Mohamad Nasir Othman, Md. Pauzi Abdullah and Yang Farina Abi. Aziz, Sains Malaysiana, 39(1), 51(2010).

18. Sujitha Ravulapalli and K. Ravindhranath, Journal of Fluorine Chemistry, 193, 58(2017), DOI: 10.1016/j.jfluchem.2016.11.013

19. A.Naga Babu, G.V.Krishna Mohan, K. .Kalpana and K .Ravindhranath, Journal of Environmental Chemical Engineering, 6, 906 (2018), DOI:10.1016/j.jece.2018.01.014

20. S. Ravulapalli, K. Ravindhranath, Journal of the Taiwan Institute of Chemical Engineers, 101, 50(2019), DOI:10.1016/j.jtice.2019.04.034 
RASĀYAN J. Chem.

Vol. 13 | No. 4 |2653-2663| October - December | 2020

21. Mohamed E.Goher, Ali M.Hassa, Ibrahim A.Abdel-Moniem, Ayman H.Fahmy, Mohamed H.Abdo, Seliem M.El-sayed, The Egyptian Journal of Aquatic Research, 41(2), 155(2015), DOI: 10.1016/j.ejar.2015.04.002

22. Shaban El-Sayed Ghazy, Salem El-Sayed Samra, Abd El-Fattah Mohammed Mahdy, and Sherin Mohammed El-Morsy, Analytical Sciences, 22(3), 377(2006), DOI:10.2116/analsci.22.377

23. C. Septhum, S. Rattanaphani, John Bremner and Vichitr Ratta, Journal of Hazardous Materials, 148(1-2), 185(2007), DOI:10.1016/j.jhazmat.2007.02.024

24. Anna Aruna Kumari and K. Ravindhranath, Journal of Chemical and Pharmaceutical Research, 4 (5), 2836(2012).

25. P. Lodeiro , A. Gudiña , L. Herrero, R. Herrero, Sastre de Vicente ME., Journal of Hazardous Materials, 178 (1-3), 861(2010), DOI:10.1016/j.jhazmat.2010.02.017

26. Anna Aruna Kumari and K. Ravindhranath, Asian Journal of Water, Environment and Pollution, 15 (1), 23(2018), DOI: 10.3233/AJW-180003

27. P. K. Meghana, A. Aruna Kumari, K. V. Pravalika, P. J. Sriram, and K. Ravindhranath, Rasayan Journal of Chemistry, 12(1), 338(2019), DOI:10.31788/RJC.2019.1215064

28. Anna Aruna Kumari and K. Ravindhranath, International Journal of ChemTech Research, 4(4), 1733 (2012).

29. M. W. Jayaweera , J.C.Kasturiarachchi and R.K. Kularatne , S.L. Wijeyekoon, Journal of Environmental Management, 87(3), 450(2008), DOI:10.1016/j.jenvman.2007.01.013

30. G. H. Jeffery, J. J. Bassett, J. Mendham and R. C. Denney, Vogel's Textbook of Quantitative Chemical Analysis, Addison Wesley Longman Limited, Ed 5, 678 (1989).

31. R. K. Trivedy, Pollution Management in Industries, Environmental Publications, KARAD, India (1979).

32. Metcalf and Eddy, Wastewater Engineering: Treatment of Reuse. $4^{\text {th }}$ Ed., McGraw Hill Co., New York (2003)

33. Albert Cotton F. and Geoffrey Wilkinson (1988), Advanced Inorganic Chemistry, Ed. John Wiley and Sons, New York, 1988, 5,216.

34. S. Ravulapalli, K. Ravindhranath, Journal of Environmental Chemical Engineering, 6(4), 4298 (2018), DOI:10.1016/j.jece.2018.06.033

35. Z. Bouberka, S. Kaoha, Kamecha, S. Elmaleh, Z. Derriche, Journal of Hazardous Materials, 119(13), 117(2005), DOI:10.1016/j.jhazmat.2004.11.026

36. A. Naga Babu, D.S. Reddy, G.S. Kumar, K. Ravindhranath, G.V. Krishna Mohan, Journal of Environmental Management, 218, 602(2018), DOI:10.1016/j.jenvman.2018.04.091

37. M. Suneetha, and K. Ravindhranath, Indian Journal of Chemical Technology, 25(4), 345(2018).

38. H.M.F. Freundlich, The Journal of Physical Chemistry,57, 385(1906)

39. M. Suneetha, B. Syama Sundar and K. Ravindhranath, Journal of Analytical Science and Technology,6, Article 15(2015), DOI:10.1186/s40543-014-0042-1

40. I. Langmur, Journal of American Chemical Society, 40, 1361(1919).

41. M. Suneetha, B. Syama Sundar and K. Ravindhranath, International Journal of Environmental Technology and Management, 18(3), 420(2015), DOI:10.1504/IJETM.2015.073079

42. Y.S. Ho, G. McKay,Process Biochemistry, 34(5), 451(1999), DOI:10.1016/S0032-9592(98)00112-5

43. Y.S. Ho, J.C.Y. Ng, G. McKay, Separation and Purification Methods, 29(2), 189(2000), DOI:10.1081/SPM-100100009

44. W.J.Weber Jr., C. Morris, Journal of the Sanitary Engineering Division, 89, 31(1963).

45. C. Aharoni, M. Ungarish, J. Chem. Soc. Faraday Trans, 1: Phys. Chem. Condens. Phases, 73(3), 456-(1977), DOI:10.1039/F19777300456

46. M. Ozacar, I.A. Sengil, Process Biochemistry, 40, 565(2005), DOI:10.1016/j.procbio.2004.01.032

47. C. Gerente, V.K.C. Lee, P. Le Cloirec, G. McKay, Critical Reviews in Environmental Science and Technoloy, 37(1), 41(2007), DOI:10.1080/10643380600729089

[RJC-6009/2020] 